\title{
THE EFFECTIVENESS ANALYSIS OF VILLAGE FUND PROGRAMS AND THEIR EFFECT ON DEVELOPMENT, EMPOWERMENT, AND WELFARE OF VILLAGE COMMUNITIES IN MENDOYO, JEMBRANA
}

\author{
Wijaya G.C. ${ }^{*}$, Marhaeni A.A.I.N. \\ Faculty of Economics and Business, University of Udayana, Bali, Indonesia \\ *E-mail: d.crisna10@gmail.com
}

\begin{abstract}
Development disparity between villages and cities has led the government to implement village funds policies to improve better development and reduce income inequality between villages and cities. This study aims to analyze the following: 1) the effectiveness of village fund programs; 2) the effect of village fund programs on village development and empowerment of village communities; 3 ) the effect of village fund programs, village development and empowerment of rural communities on community welfare; 4) the role of village development and empowerment of village communities in mediating the effect of village fund programs on community welfare. This study was conducted in Mendoyo, Jembrana. The samples of this study were 115 respondents taken using simple random sampling with lottery method. Data collection methods used was observation, interviews and in-depth interviews. The data analysis technique used was descriptive statistical analysis and Structural Equation Modeling (SEM) and the Partial Least Squares (PLS) are conducted to statistically test the model. The results of the analysis show that the village fund program in Mendoyo, Jembrana is relatively effective. Village fund programs have a positive and significant effect on village development and empowerment of rural communities. The village fund program does not have a significant effect on community welfare, but village development and empowerment of rural communities have a positive and significant effect on community welfare. Village development and empowerment of village communities fully mediate the influence of village fund programs on community welfare; given that village fund programs are directly insignificant towards community welfare.
\end{abstract}

\section{KEY WORDS}

Effectiveness, village funds, development, empowerment, welfare.

National development in its implementation is facing problems of development such as development disparity between villages and cities. Inequality between regions will make population migration and capital migration from underdeveloped regions to developed regions (Cherodian and Thirlwall, 2013). Inequality in development is also caused by demographic differences between regions. The government's strategy to resolve the development disparity is implementing nation-wide development which focuses on village development.

The Undang-undang (UU) No. 32 of 2004 as amended by UU No. 23 of 2014 concerning Regional Government, explains the existence of a decentralized system, like the delegation of government affairs by the Central Government to Regional Governments. The village is the lowest level of regional government. Villages have a strategic role in the development and improvement of community welfare. The UU No. 6 of 2014 concerning Villages, where villages are given adequate authority and sources of funds through village funds to manage their potential for economy and prosperity improvement of the community. The purpose of the Village Fund is to improve public services in the village, alleviate poverty, advance the village economy, overcome inter-developmental disparities, and strengthen village communities as subjects of development (UU No. 6, 2014). Based on Government Regulation Number 8 of 2016, the priority of village funds is to develop and empower the rural communities. 
Based on the policy of reformulating the distribution of village funds in 2018, the distribution of Village Funds was channeled by calculating 77 percent based on equity (Basic Allocation), 3 percent based on affirmation for disadvantaged villages and very lagging villages (Affirmation Allocation) and 20 percent (Formula Allocation) based variable number of villagers (10 percent), number of poor people (50 percent), village area (15 percent), and village geographical difficulty level (25 percent). The Village Fund Distribution is divided into two stages, such as the first stage (to be finished soon in March and the latest in July) of 60 percent and the second stage (to be finished soon in August) of 40 percent (PMK 50/2017).

The success of the Village Fund Program can be seen through the Village Development Index (IPD). IPD is a measure prepared to assess the level of progress or development of villages in Indonesia with its unit of analysis which substantially and together describes the level of development in the village. In the period of 2014 to 2018, there were three villages which has increased their status from the developing village into independent village. The number was classified as very small compared to the number of village status improvements in other Districts or Cities. This has caused Jembrana need of Village Fund assistance to improve village development and the empowerment of rural communities to increase the village development index.

The obstacles on managing village funds are the capacity of human resources in the village government and the low level of community participation (Aziz, 2016). According to the Supreme Audit Agency, there are problems in village financial management such as in governance and financial reporting due to the lack of knowledge of village officials, so that there is potential for fraud or corruption. Village development can be successful due to several factors, like village capacity, community participation and village head leadership (Nurjaman, 2015).

The purpose of this study is to analyze as follows: 1) the effectiveness of the village fund program; 2) the effect of village fund programs on village development and empowerment of village communities; 3 ) the effect of village fund programs, village development and empowerment of rural communities on community welfare; and 4) the role of village development and empowerment of village communities in mediating the effect of village fund programs on community welfare.

\section{LITERATURE REVIEW}

Economic development is a process that causes rise of income per capita of a country's population continuously in the long period. According to Todaro (2006) the success of economic development is shown by three basic values, such as the development of the people's ability to meet basic needs, the increasing sense of self-esteem of people as humans, and the increased ability of the community to choose (freedom from servitude) which is one of human rights.

Administration of development is the efforts that carried out by the village to grow, develop, and change consciously and planned in all aspects of the life and livelihood of the village concerned to achieve the ultimate goal. Development activities in villages by Jayadinata (2006: 87) are the fields of economy, social, physical and infrastructure and government. Village Development is an effort to improve the quality of life and life for the greatest welfare of the village community. Rural development is a rural concept of development which focuses on the social and cultural characteristics of people in rural areas. Effective development is not solely caused by opportunities but it is the result of determining priority choices of activities by good planning (Jafar, 2015).

Effectiveness is the utilization of resources, facilities and infrastructure in a certain amount which is consciously set beforehand to produce a number of goods for the services of the activities carried out. Effectiveness is always related to the relationship between the actual results achieved (Wambrauw, 2013). Effectiveness is a measure that states how far the target (quantity, quality and time) has been achieved by management, which target has been determined in advance. 
Empowerment--based on the Indonesian Ministry of Social Affairs--implies the recognition of the potential for giving trust and opportunities to encourage independence and increase the ability to solve problems. The meaning of empowerment for government circles can be identified as an effort to foster. The community can achieve their welfare must be fostered because they are in poor condition. This effort includes three things, such as first, encouraging, motivating, increasing awareness of its potential and creating a climate or atmosphere to develop. Second, strengthen the power of potential and positive steps to develop it. Third, providing various inputs and opening up access to opportunities.

Village government based on UU Number 72 of 2005 concerning Villages, Article 6 states that the Village Government is the administration of government affairs by the Village Government and the Village Consultative Body in regulating and managing the interests of the local community based on local origins and customs that are recognized and respected in the system of Government of the Republic of Indonesia. The Village Head is a policy implementer while the Village Consultative Body is a policy making and supervisory institution (village regulation). Village finance is all village rights and obligations that can be valued with money and everything in the form of money and goods related to the implementation of village rights and obligations. The rights and obligations referred cause income, expenditure, financing, and management of village finances.

Village Funds are aid funds allocated to the Village Government that are used to improve community service facilities, institutions, and village infrastructure that are needed and prioritized by the community, whose utilization and administration are carried out and accounted for by the Village Head. The purpose of the Village Fund is to provide stimulant assistance or stimulant funds to encourage the funding of the Village Government program which is supported by the participation of community self-help in implementing government activities and community empowerment.

Harrod Domar's theory of savings and investment emphasizes that community development is only a matter of providing capital and development investment is nothing but investment. This theory is based on the assumption that development problems are basically a problem of adding capital investment. The problem of underdevelopment is the problem of lack of capital. Development requires investment as a driver of production. From this productivity, it will absorb the workforce that forms labor regulations while contributing to the state in the form of taxes.

Human Capital Theory: David McCleland is based on the assumption that development problems are basically a problem of adding capital investment. This theory explains that the higher the level of education, the higher the level of income. The higher the level of income, the higher the skills and knowledge. With the higher skills and knowledge, the higher the level of productivity. With the existence of high skills and knowledge, it encourages high levels of income.

The level of welfare includes food, education, health, sometimes also associated with employment opportunities, old age protection, and freedom from poverty and so on. According to Albert and Robin (1999), the theory of community welfare is basically divided into two, such as social welfare theory and economic welfare theory. Social welfare theory can be classified into utilitarian classical, neoclassical welfare theory, and new contractarian approach. Classical utilitarian approaches emphasize pleasure (pleasure) or satisfaction (utility).

\section{CONCEPTUAL FRAMEWORK}

Village development is an effort made to improve the quality of life and the lives of people in an area where village development is carried out by all levels of both government and society (Sutoro, 2014). Based on a study conducted by Feiby, et al (2017), the Village Fund program policy has an impact on increasing the economy of the community. It is due to an increase in infrastructure of agricultural roads so that access to transportation from plantation locations can be easier and speed up the process of selling results- agricultural product. 
A study conducted by Dydha (2017) on the influence analysis of Village Funds on the village infrastructure development and rural communities empowerment showed that the Village Fund had a positive effect on the development of village infrastructure as a support for the economy in the form of increasing SMEs. The community will become more economically prosperous if empowerment is carried out more intensively and well-structured which is supported by good cooperation by the community and the government. Community empowerment is carried out so that people are more independent in economic terms so that they will be strong enough in competition. Based on research from Yamulia (2018) regarding the management of village funds in empowering rural communities, it was shown that the first supporting factor for managing village funds was support from a complete policy. The second one would be the socialization of village fund management that had been followed by village officials. Empowerment activities are prioritized for physical empowerment such as road and waste construction, while non-physical empowerment is related to official village government training and Family Welfare Empowerment (PKK).

The study conducted by Muhammad, et al (2017) regarding the effectiveness of village funds for the development of community participation-based economic potential shows that the use of the Village Fund is very effective, especially in the development of village economies to empower people who can ultimately help improve the economy. The participation or initiative of the village government is also very important in the context of empowering rural communities because the main authority of the village government is planning. In the process of development planning the community is always actively participating, especially in musrenbang (Musyawarah Rencana Pembangunan, development plan discussion) activities so that community empowerment can run well.

In this section we will describe the relationship between research variables to clarify which variables function as independent variables and dependent variables. The conceptual framework of this research shows the relationship between independent variables and dependent variables, where the dependent variables are village development, community empowerment, and community welfare while the independent variables include the Village Fund program.

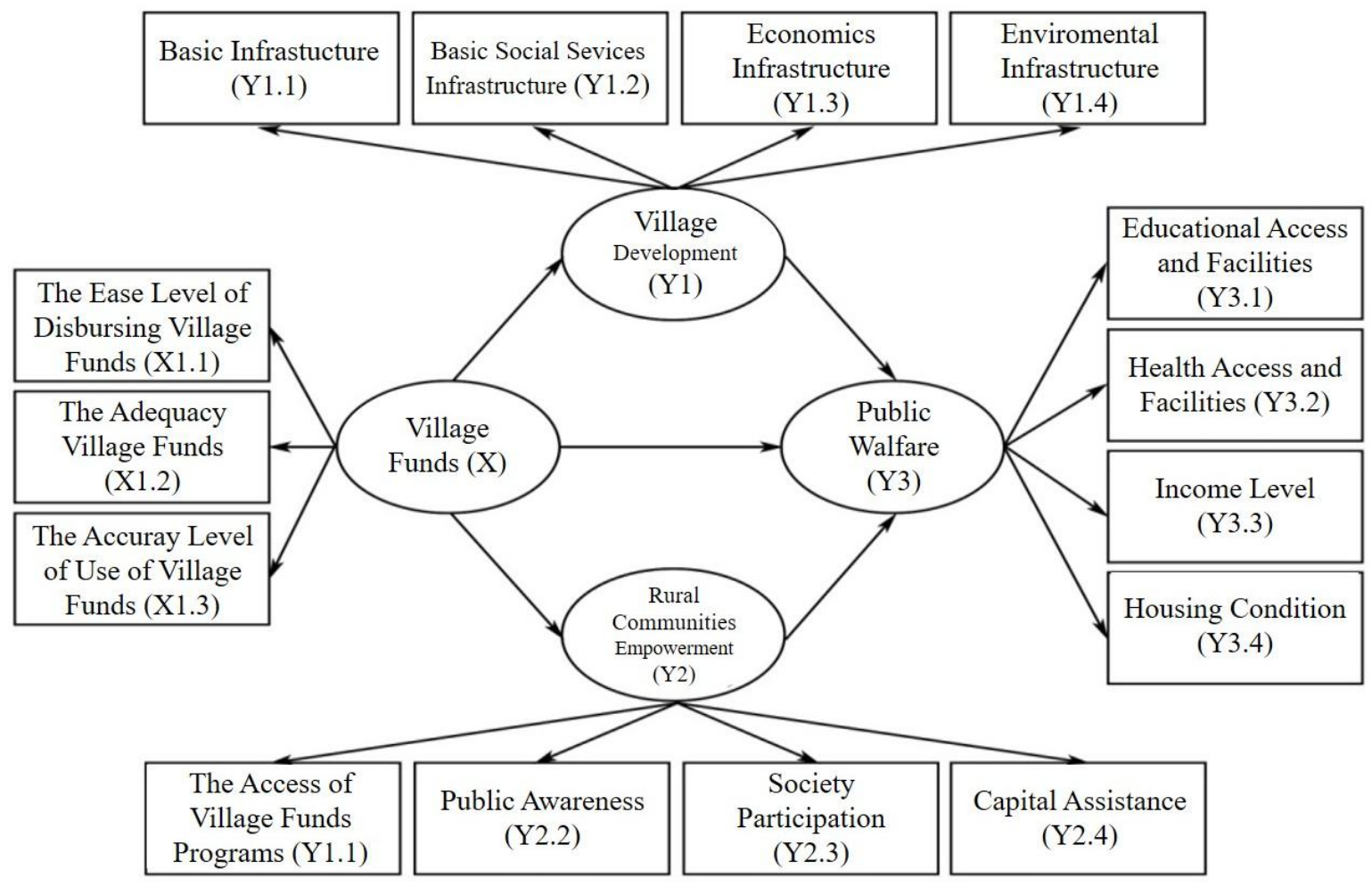

Figure 1 - The Effectiveness Analysis of Village Fund Programs and Their Effects on Development, Empowerment, and Village Community Welfare in Mendoyo, Jembrana 
Based on empirical studies, hypotheses can be formulated to provide direction for research analysis:

- The Village Fund Program has a positive effect on village development and the empowerment of rural communities in Mendoyo District, Jembrana Regency;

- The Village Fund Program, village development, and village community empowerment have a positive effect on community welfare in Mendoyo District, Jembrana Regency;

- Village development and empowerment of village communities mediate the influence of the Village Fund Program on community welfare in Mendoyo District, Jembrana Regency.

\section{METHODS OF RESEARCH}

This study used a quantitative method that aims to test the hypotheses that have been determined, besides that, this study also used descriptive statistical analysis and analysis of Structural Equation Modeling (SEM) using Partial Least Square PLS. The location of this study is in Mendoyo District, Jembrana Regency, Bali Province. The objects of this study are the effectiveness of the Village Fund Program, the influence of the Village Fund Program on village development, the empowerment of village communities, and the welfare of the community in Mendoyo District, Jembrana Regency.

The variables analyzed in this study include the Village Fund Program variable as measured by indicators of the ease of disbursing village funds, the adequacy of village funds, and the level of accuracy of the use of village funds. Village development variables which are measured by indicators of basic infrastructure, facilities for basic social services, economic infrastructure, and environmental infrastructure. Community empowerment variables measured by indicators of access to village fund programs, public awareness, community participation, and capital assistance. Community welfare variables measured by indicators of education access and facilities, access and health facilities, income level, and housing conditions.

The type of data in this study used is quantitative data which included the number of villages that received the Village Fund Program in Bali Province, the number of villages in Jembrana Regency, the number of village officials and community elements in Mendoyo District, Jembrana Regency, and qualitative data which included information about the research location and regarding government programs in an effort to improve village quality and community welfare. This research uses primary data sources by conducting observations, interviews and in-depth interviews with village officials and community elements as well as quantitative data such as a list of villages receiving village fund allocation programs, the number of village officials and elements of the village community in Mendoyo, the amount of village funds given to each village, the demographics of the subdistricts declined. The population in this study were village officials and community elements totaling 161 people with a sample of 115 respondents determined by the Slovin method and the sampling technique used was simple random sampling using the lottery method. The data analysis used was descriptive statistical analysis and Structural Equation Modeling (SEM) using Partial Least Squares (PLS). The model of the equation in this study in accordance with Figure 1 is formulated as below.

$$
\begin{aligned}
& Y_{1}=\beta_{1} X+\varepsilon_{i} \\
& Y_{2}=\beta_{2} X+\varepsilon_{i} \\
& Y_{3}=\beta_{3} X+\beta_{4} Y_{1}+\beta_{5} Y_{2}+\varepsilon_{i}
\end{aligned}
$$

Where: $X=$ village fund program, $Y_{1}=$ village development, $Y_{2}=$ village community empowerment, $Y_{3}=$ community welfare, $\beta_{1}, \ldots, \beta_{5}=$ loading factor, $\varepsilon_{i}=$ noise or measurement error. 


\section{RESULTS OF STUDY}

Characteristics of Respondents. Respondents of this study were dominated by male as much as 84.3 percent and women as much as 15.7 percent. It means that the respondents in this study were dominated by male, because generally jobs as village officials and community leaders tend to be done by men. Respondents with age range of 20-29 years occupy the smallest position that is equal to 6.1 percent of the total samples available, while respondents with the highest number are in the age range of 40-49 years with a percentage of 39.1 percent of the total samples available. This means that work as village officials and community leaders is still dominated by people of productive age.

Respondents have educational levels ranging from junior high school to graduate level. In this study, the majority of respondents were educated to graduate high school, amounting to 80.9 percent, then Diploma-educated respondents by 2.6 percent, and respondents who were educated up to the Bachelor level were 15.7 percent. In this study, respondents who had a low educationlevel did not dominate. Only a small percentage of respondents are junior high school graduates. Respondents who were only able to reach the junior high school level were 0.9 percent. Education is very influential in managing village funds. With high or enough education allows the respondent to be able to manage assistance from the village fund program on target. In general education has a positive influence on productivity.

All respondents in this study included village officials and community elements which included the village head, village secretary, village affairs head, village section head, neighborhood or hamlet head, BPD chairman, and LPM chairman. Respondents in this study were dominated by respondents as head of the neighborhood or hamlet with a percentage of 32.2 percent. Respondents as village heads accounted for at least 5.2 percent of the total sample. This means that the management of village funds is carried out by village officials and village institutions involving village communities.

Outer Model Testing. Convergent validity of a measurement model that has a reflective indicator can be assessed from loading factors (i.e. a correlation between item score or component score and construct score) indicators that measure the construct. An indicator can be declared valid if it has a loading factor above 0.6 for the intended construct. All loading factors in this research indicator have values greater than 0.6. This shows that the terms of convergent validity have been fulfilled. Furthermore, to test discriminant validity, measurement of discriminant validity from the measurement model can be assessed based on cross-loading measurement indicators with the construct. Correlation of construct indicators in this study has a higher value than the correlation of these indicators with other constructs, it is said that the construct has high discriminant validity. Cronbach's Alpha measures the lower limit of the reliability value of a construct, whereas Composite Reliability measures the true value of the reliability of a construct (Chin and Gopal in Salisbury et al, 2002). The Role of thumb of the value of Cronbach's Alpha or Composite Reliability must be greater than 0.7, but if the results obtained are close to 0.7 (such as 0.6), this is still acceptable in exploratory studies (Hair et al, 2006). The Cronbach's Alpha and Composite Reliability values from each construct in this study are greater or close to 0.70 so that the measure used in this study is reliable. The result of Q2 calculation is 0.876 so that it can be said to have a strong predictive prevalence, so that the resulting model is feasible to predict. The number of 0.876 can be interpreted that the variation in community welfare by 87.6 percent can be explained by variations in the village fund program, village development, and empowerment of rural communities, while the remaining 13.4 percent is explained by other variables outside the model.

Effectiveness of the Village Fund Program. The effectiveness of the village fund program implementation in the village fund program variable is quite effective with an effectiveness value of 78.50 percent. Effectiveness of implementing village fund programs on variables village development is classified as effective with the effectiveness of 78.75 percent. Effectiveness the implementation of the village fund program on the variable of empowering village communities is classified as effective with an effectiveness value of 75.50 percent. Effectiveness of implementing village fund programs on variables community 
welfare is classified as effective with an effectiveness value of 78.50 percent. Based on the results of the effectiveness values of each of these variables, the effectiveness of the village fund program is classified as effective in Mendoyo District, Jembrana Regency with an effectiveness value of 77.75 percent.

Effect of Village Fund Programs on Village Development. The village fund program has a positive and significant effect on village development with $p$ value $=0,000$ with the equation function: $Y_{1}=0.529 \mathrm{X}$. Village funds really help the village government to realize infrastructure policies and development and can prosper the village community which is far from prosperous for the central government. Sujiono (2006) states that there are several factors that can influence the level and direction of village development, such as location factors, regional facilities and infrastructure including connecting roads. Before the existence of village funds, the changes in the community were very slow, especially those caused by low income, inadequate education, and employment status that was far from normal. This result is reinforced by research from Rini (2016) The existing Village Fund usage policy has been targeted for village development and the results can also be felt by the community. This shows that the village fund program has things that can increase village development especially in physical infrastructure related to the interests of the village community. Some studies state that the existence of infrastructure is closely related to the level of development of a region, characterized by the rate of economic growth and community welfare (Calderón \& Servén, 2004; Charlery et al., 2016; Chatterjee \& Turnovsky, 2012; Démurger, 2001; Maryaningsih et al., 2014; Umiyati, 2012). From the results of interviews with the Chief of Finance of Delod Berawah Village, Ms. Ni Luh Wirani, on April 18, 2019 at the Delod Berawah Village Office also said the results were in line.

"With the assistance of this village fund program, development in the village can be more helpful in terms of funding, because in the past development was constrained by limited funding and since there was a village fund program, in the village, we became very helpful in terms of development such as the provision of infrastructure facilities education, health, connecting roads, the environment and others as well as the infrastructure that is a priority can be fulfilled".

Effect of the Village Fund Program on the Empowerment of Village Communities. The village fund program has a positive and significant effect on the empowerment of rural communities with $p$ value $=0,000$ with the equation function: $Y_{2}=0.732 X$. The use of village funds must involve the community at large, because in village funds use the needs and attitudes of the community are very important, especially in level of community participation. All village governments in Mendoyo, Jembrana have involved the community on developing their own potential and their own regions. This is supported by village funds channeled to the community, whereby the community is able to accept and participate on developing their potential and village potential. First, when planning activities and budgets, the community actively participated in planning and development meetings at the hamlet (banjar) level, which then continued to the village level. Secondly, at the time of program implementation, the role of the village community was needed, because with community support the programs and activities that had been established could run well. Third, the monitoring and evaluation process. Monitoring and evaluation must be carried out by the government to see the realization of planned programs or activities.

In addition, the government is also required to provide accountability reports for programs and activities along with the budget used at the end of each year. The report was aimed transparently at the village community. In its implementation, each village government in Mendoyo District always reports activities to the community. In addition, the village government has also reported the process carried out during the year starting from planning to evaluation. From the results of an interview with the Head of the Pergung Village Service Office, Ms. Ni Ketut Sutarmia at the Pergung Village Office on April 16, 2019 the results were in line: "In the village fund program in terms of empowering rural communities, the village government supported by all elements of the community has tried to participate in socializing the village fund program so that the community can know and be aware of its position as a community member and participate and oversee the village fund program. We have also 
given village communities access so that we can play an active role in activities from the village fund program".

This result is supported by Dyah's research (2018) which states that the types of community empowerment activities that have been carried out so far can be seen from two perspectives, first if based on the concept of law, then activities that have been implemented such as training and assistance or capital are in line with the paradigm empowerment. Research from Fossati (2016) found several things that had an effect on the success of implementing the ADD program to empower rural communities including human resource factors and socialization in the allocation of funds.

The Effect of Village Fund Program, Village Development and Village Community Empowerment on Community Welfare. Village development has a positive and significant effect on community welfare with $p$ value $=0,000$ with the function equation: $Y_{3}=0.031 X+$ $0.513 Y_{1}+0.352 Y_{2}$. Empowerment of rural communities has a positive and significant effect on people's welfare with $p$ value $=0.019$. Except for the influence of the village fund program on community welfare that is not significant with $p$ value $=0.792$. The government cannot directly provide assistance, like money to the community. The government could facilitate community welfare through village development and empowerment of village communities. The form of village development can be directed by providing basic infrastructure, economic, social and environmental facilities. Similarly, the empowerment of village communities can be directed in the form of providing access, awareness, participation and capital.

All these things must also involve the community, so they can participate on managing various potentials that may be developed. Of course this will have an impact on people's welfare. Community welfare shows a measure of the results of community development in achieving a better life that includes capacity building and equitable distribution of basic needs such as housing, health, then increased income, and better education, and increased attention to human values (Todaro and Stephen C. Smith, 2006). This is in line with the results of interviews with Mr. I Gusti Agung Kd. Bambang, as the Village Head of Mendoyo Dangin Tukad at the Mendoyo Dangin Tukad Village Office on 12 April 2019 that: "Community welfare in the village fund program is channeled through rural development activities and empowerment accordance with the priorities of the existing rules, besides that it can also control the funding provided to be more directed accordance with the needs of the community and can be felt directly by the community".

This result is supported by the research of Vitasurya (2016) and Zhang \& Xu (2016) which shows that the priority of the utilization of village funds is related to the development of village facilities and infrastructure and the empowerment of village communities based on the conditions and potential in the village, in line with the achievement of Village RPJM (Mediumterm Development Plan) and RKP (Government Action Plan) targets every year.

The Role of Village Development and Empowerment of Village Communities in Mediating the Effect of Village Fund Programs on Community Welfare. Village development and empowerment of village communities mediate the influence of village fund programs on community welfare with a $p$ value $=0,000$. The use of the majority of village funds for development is based on several considerations, first, the construction of physical infrastructure is a real need of the community. Second is the outcome, benefits and impacts of development directly felt by the community. Third, accountability is easier. Fourth, the benefits can be enjoyed by the entire community. Fifth, can create jobs for the community. Some empirical facts from the research of Calderón \& Servén (2004); Démurger, (2001); Maryaningsih, et al (2014) show that the development of infrastructure capacity in a region goes hand in hand with its economic development, this is because economic development has demanded the availability of adequate infrastructure facilities and infrastructure. The existence of infrastructure encourages increased productivity of production factors. Infrastructure improvement increases investment and economic growth, because investment will increase employment.

Inequality of infrastructure development will also play a role in the gap in economic development which leads to inter-regional welfare inequality (Démurger, 2001; Fan \& ChanKang, 2008; Surd, Kassai, \& Giurgiu, 2011; Warr, Menon, \& Rasphone, 2015). The results 
are supported by research from Roy Stevensen Iver Turere, et al (2018) which states that the Village Fund is quite capable of increasing community income, adequate education levels, providing employment opportunities, and being able to improve community development in Pineleng Subdistrict, and village funds. On supporting the level of welfare of the existing community in terms of education, health, and community income. The discussion was also supported by the results of interviews with the Chairperson of the LPM of Yeh Sumbul Village, Mr. M. Hadori on April 23, 2019 at the Yeh Sumbul Village Office, which said:

"The presence of village development as a result of the village fund program here does not only encourage the emergence of opportunities for the community in terms of income and employment, but also concerning the social status of the community".

This is in line with research from Majumder (2012) showing that adequate infrastructure can increase average living standards and reduce poverty. The same thing can be supported by Feiby (2017) research which states that the community economy is increasing after the Village Fund program. This is due to an increase in infrastructure of agricultural roads, so that access to transportation from the plantation site is easier, thus accelerating the process of selling agricultural products. Infrastructure facilities can play an important role in regional development (Kateja \& Maurya, 2011).

According to Chambers (1995) community empowerment is an economic development concept that summarizes social values. This concept reflects the new development paradigm, which is "people-centered, participatory, empowering, and sustainable". Community empowerment as a model of community-based development is an effort to increase the dignity of our people who are still trapped in poverty and underdevelopment. If viewed from the point of administering State administration, the community empowerment is not solely an economic concept but implicitly contains the notion of enforcing economic democracy, it is an economic activities that take place from the people, by the people and for the people (Dyah et al. 2018).

The purpose of community empowerment is basically to help authentic and integral human development from weak, poor, marginal and small communities and empower these community groups in a socio-economic manner so that they can be more independent and can fulfill their basic needs, but are able to play a role and in community development (Sumaryadi, 2005). Empowerment refers to the conditions or outcomes that a social change wants to achieve, like, a empowered community, has the power or knowledge and ability to fulfill its needs, both physical, economic and social, such as having self-confidence, being able to express aspirations have a livelihood, participate in social activities, and be independent in carrying out their life's tasks.

\section{CONCLUSION AND SUGGESTIONS}

The effectiveness of the Village Fund Program, which is seen from the village fund program variable, village development, village community empowerment and community welfare, is classified as successful and effective in Mendoyo, Jembrana, Bali with an effectiveness value of 77.75 percent. This can be seen from the effectiveness of the village fund program variable of 78.50 percent which is considered effective, the effectiveness of the village development variable is 78.75 percent which is classified as effective, the effectiveness of the village community empowerment variable is 75.50 percent which is classified as effective, and the effectiveness of the community welfare variable is 78.50 percent which is considered effective. Village fund programs have a positive and significant effect on village development and empowerment of rural communities in Mendoyo, Jembrana. The village fund program directly does not have a significant effect on community welfare, but village development and empowerment of rural communities have a positive and significant effect on the welfare of the community in Mendoyo, Jembrana, Bali. Village development and empowerment of village communities fully mediate the influence of village fund programs on community welfare in Mendoyo District, Jembrana District, given that village fund programs are not directly significant to community welfare. 
Based on the results of the analysis and conclusions obtained, we suggest that the role of officers is expected to be more active in disseminating and providing explanations regarding village fund programs so that the elderly and those who have low education can understand well. Collaboration between the government and the community is also necessary in this regard so that the village fund program really provides great benefits for the community in particular and the village in general.

\section{REFERENCES}

1. Albert, Michael and Robin Hahnel. 1999. Marxismand Socialist Theory: Socialism in Theory and Practice.

2. Aziz Nyimas Latifah Letty. 2016. Otonomi Desa dan Efektivitas Dana Desa. Jurnal Penelitian Politik, 13(2), 193-211.

3. Calderón, C., \& Servén, L. 2004. The Effects of Infrastructure Development on Growth and Income Distribution (Working Papers No. 3400). Working Papers No. 3400. doi: 10.1596/1813-9450-3400.

4. Cantarero, Rodgrigo., Potter, James. 2014. Quality of Life, Perceptions af Change, and Psicological Well-being of the Elderly Population in Small Rular Towns in the Midwest.International Journal of Aging and Human Development. Vol. 78. pp: 1-18.

5. Chambers, R. 1995. Rural Development: Putting the Last First. London; New York.

6. Charlery, L. C., Qaim, M., \& Smith-Hall, C. 2016. Impact of Infrastructure on Rural Household Income and Inequality in Nepal. Journal of Development Effectiveness, 8(2), 266-286.

7. Chatterjee, S., \& Turnovsky, S. J. 2012. Infrastructure and Inequality. European Economic Review, 56(8), 1730-1745.

8. Cherodian, Rowan dan A. P. Thirlwall. 2013. Regional Disparities in Per Capita Income in India: Convergence and Divergence?. Discussion Papers. School of Economics, University of Kent, Canterbury, Kent.

9. Chin, W. W. 1998. The Partial Least Squares Approach for Structural Equation Modeling. In G. A. Marcoulides (Ed.), Modern Methods for Business Research (pp.295-236). London: Lawrence Erlbaum Associates.

10. Démurger, S. 2001. Infrastructure Development and Economic Growth: an Explanation for Regional Disparities In China? Journal Of Comparative Economics, 29 (1), 95-117.

11. Dyah Adriantini Sintha Dewi, Habib Muhsyin Syafingi, Alan Bayu Aji. 2018. Paradigma Aparatur Desa dalam Penggunaan Dana Desa untuk Pemberdayaan Masyarakat. Jurnal Pandecta. Vol. 13.No. 2. Page 139-149.

12. Dydha, Dimas Okta. 2017. Analisis Pengaruh Dana Desa Terhadap Pembangunan Infrastruktur Desa dan Pemberdayaan Masyarkat Desa (Studi pada Desa Randuagung Kecamatan Kebomas Kabupaten Gresik). Jurnal JS Local Government Municipal Government.

13. Fan, S., \& Chan-Kang, C. 2008. Regional Road Development, Rural and Urban Poverty: Evidence From China. Transport Policy, 15(5), 305-314.

14. Feiby Vencentia Tangkumahat, Vicky V. J. Panelewen, Arie D. P. Mirah. 2017. Dampak Program Dana Desa terhadap Peningkatan Pembangunan dan Ekonomi di Kecamatan Pineleng Kabupaten Minahasa. Jurnal Agri-Sosio Ekonomi Unsrat, ISSN 1907- 4298, Volume 13 Nomor 2A.

15. Fossati, D. 2016. Beyond "Good Governance": The Multi-level Politics of Health Insurance for the Poor in Indonesia. World Development. Vol. 87, Page : 291-306.

16. Hair, et al. 2006. Multivariate Data Analysis. Sixth Edition. New Jersey: Pearson Education

17. Jafar, Marwan. 2015. Perencanaan Pembangunan Desa. Kementerian Desa, PDTT. Jakarta.

18. Kateja, A., \& Maurya, N. 2011. Inequality in Infrastructure and Economic Development: Interrelationship Re-Examined. The Indian Economic Journal, 58(4), 111-127. 
19. Li, T. M. 2016. Governing Rural Indonesia: Convergence on the Project System. Critical Policy Studies, Vol. 10(1), 79-94.

20. Majumder, R. 2012. Removing Poverty and Inequality in India: The Role of Infrastructure. Munich Personal Repec Archive. (MPRA Paper No. 40941.

21. Maryaningsih, N., Hermansyah, O., Savitri, M. 2014. Pengaruh infrastruktur terhadap pertumbuhan ekonomi Indonesia.Buletin Ekonomi Moneter dan Perbankan, Vol. 17(1), Hal: 61-98.

22. Menkhoff, Lukas. \& Rungruxsirivorn, Omsiri. 2010. Do Village Fund Improve Access To Finance? Evidence From Thailand. Journal of Word Development, Elsevier Ltd, Volume 39.

23. Muhammad Eko Atmojo, Helen Dian Fridayani, Aulia Nur Kasiwi, Mardha Adhi Pratama. 2017. Efektivitas Dana Desa untuk Pengembangan Potensi Ekonomi Berbasis Partisipasi Masyarakat di Desa Bangunjiwo. Jurnam Umpo, Vol. 5. No. 1.

24. Nurjaman, R. 2015. Dinamika dan Problematika Implementasi UU Desa: Pembelajaran dari 2 Daerah di Jawa Barat. Jurnal Desentralisasi. 13(1).

25. Peraturan Menteri Keuangan Nomor 49/PMK.07/2016 tentang Tata Cara Pengalokasian, Penyaluran, Penggunaan, Pemantauan, dan Evaluasi Dana Desa.

26. Rini Listiyani. 2016. Efektivitas Implementasi Kebijakan Penggunaan Dana Desa Tahun Anggaran 2015 di Desa Gunungpring Kecamatan Muntilan Kabupaten Magelang. Fakultas IImu Sosial, Universitas Negeri Yogyakarta.

27. Roy Stevensen Iver Turere, Debby Ch. Rotinsulu, Een N. Walewangko. 2018. Efektivitas Dana Desa (DD) Terhadap Peningkatan Kesejahteraan Masyarakat di Kecamatan Pineleng, Kabupaten Minahasa. Jurnal Pembanguan Ekonomi dan Keuangan Daerah, Vol. 19, No. 6, Hal.16.

28. Sujiono. P. 2006. Manajemen Pelayanan Publik. Cendekia. Jakarta hal. 235.

29. Sumaryadi, I Nyoman.2005. Perencanaan Pembangunan Daerah Otonom dan Pemberdayaan Masyarakat. Jakarta: Citra Utama .

30. Surd, V., Kassai, I., \& Giurgiu, L. 2011. Romania Disparities in Regional Development. In Procedia - Social and Behavioral Sciences. Vol. 19. Page: 21-30.

31. Sutoro Eko, Khasanah, Titik Istiyawatun, Dyah Widuri, Suci Handayani, Ninik Handayani, Puji Qomariah, Sahrul Aksa, Hastowiyono, Suharyanto, Borni Kurniawan. 2014. Desa Membangun Indonesia. Yogyakarta: Forum Pengembangan Pembaharuan Desa (FPPD).

32. Todaro, Michael P. dan Stephen C. Smith. 2006. Pembangunan Ekonomi (Edisi Kesembilan, Jilid I). Jakarta : Erlangga

33. Umiyati, E. 2012.Analisis Tipologi Pertumbuhan Ekonomi dan Disparitas Pendapatan dalam Implementasi Otonomi Daerah Di Propinsi Jambi. Jurnal Paradigma Eonomika, Vol. 1(5), Hal: 15-21.

34. Undang-Undang Nomor 6 Tahun 2014 Tentang Desa.

35. Undang-Undang Republik Indonesia Nomor 12 Tahun 2008 tentang perubahan Kedua Atas UU Nomor 32 Tahun 2004 tentang Pemerintahan Daerah.

36. Vitasurya, V. R. 2016. Local Wisdom for Sustainable Development of Rural Tourism, Case on Kalibiru and Lopati Village, Province of Daerah Istimewa Yogyakarta. Procedia Social and Behavioral Sciences, Vol. 216, pp: 97-108.

37. Wambrauw Ari Yohan. 2013. Efektivitas Pelaksanaan Peraturan Daerah Perpajakan dan Retribusi Daerah dalam Memperoleh Pendapatan Asli Daerah di Kabupaten Supiori Provinsi Papua.e-Journal. Fakultas Hukum Universitas Atma Jaya Yogyakarta.

38. Warr, P., Menon, J., \& Rasphone, S. 2015. Public Services and the Poor in Laos. World Development, 66, 371-382.

39. Yamulia Hulu, R., Harahap, Hamdani, Nasution, Muhammad Arif. 2018. Pengelolaan Dana Desa dalam Pemberdayaan Masyarakat Desa. Jurnal Pendidikan IImu-IImu Sosial Volume 10 (1), Hal: 146-154.

40. Zhang, J., \& Xu, L. C. 2016. The Long-run Effects of Treated Water on Education: The Rural Drinking Water Program in China. Journal of Development Economics, 122, 1-15. 